\title{
142. Motilitätsstörung des Magens nach Vagotomie und Pyloroplastik
}

\author{
H. G. Beger, M. Meves, R. Bittner, E. Kraas und H. Gögler
}

Chirurg. Universitätsklinik u. Poliklinik (Direktor Prof. Dr. E. S. Bücherl) Klinikum Charlottenburg, FU Berlin

\section{Impaired Motility of the Stomach after Vagotomy and Pyloroplasty}

Summary. In 94 patients suffering from duodenal ulcer, stomach emptying was' observed by means of a labeled nutrition specimen before and after organ-conserving gastric surgery. The surgical procedure was: (1) selective gastric vagotomy + Finney pyloroplasty (24 patients);(2) selective gastric vagotomy + partial pyloromyectomy (26 patients); (3) selective proximal vagotomy + partial pyloromyectomy (16 patients); (4) selective proximal vagotomy (17 patients). In all these patients the operation provoked slow stomach emptying during the early postoperative period. The duration of the period of slow stomach emptying-in some cases up to one year-depends on the type of vagotomy performed and the extent of the division of the musculature of the antrum.

Key words: Vagotomy, selective - Drainage - Stomach, emptying.

Zusammenfassung. Bei 94 Patienten mit einem Ulcus duodeni wurde die Magenentleerung einer markierten Nahrungsprobe vor und nach organerhaltenden Magenoperationen gemessen. Op.-Verfahren: 1. selekt. gastr. Vagotomie + Finney-Pl. (24 Pat.); 2. selekt. gastr. V. + part. Pylormyektomie (26 Pat.); 3. selekt. prox. V. + part. Pylormyektomie (16 Pat.); 4. selekt. prox. V. (17 Pat.). Bei allen Patienten bewirkte die Operation eine Verzögerung der Magenentleerung in der frühpostoperativen Periode. Die Dauer der Magenentleerungsverzögerung - z. T. bis zu einem Jahr postoperativ - hängt ab vom Typ der Vagotomie und dem Ausmaß der Durchtrennung der Antrummuskulatur.

Schlïsselwörter: Selektive Vagotomie - Pyloroplastik - Magenentleerung.

\section{Das Rezidivulcus nach selektiver proximaler Vagotomie}

\author{
Th. Juninger, A. Kallenberg, J. Müller und H. Pichlmaier \\ Chir. Klinik Köln-Lindenthal
}

\section{Recurrent Ulceration after Proximal Selective Vagotomy}

Summary. Between 1971 and 1974,348 patients with duodenal ulcer were subjected to proximal selective vagotomy (SPV). The ulcer recurrence rate was 7.7 percent, 1 to 4 years after operation; it increased as time elapsed and was not significantly lower in patients with pyloroplasty. In 29 patients with gastric ulcer, 6 recurrent ulcers were observed in 17 patients after SPV alone, and no recurrent ulcer was noted in the 12 patients treated by SPV and pyloroplasty. The commonest cause of recurring duodenal ulcer is an incomplete vagal section (11 of the authors' own 15 cases). In an effort to avoid this the authors have begun a controlled clinical trial of the electrical stimulation test.

Key words: Ulcer recurrent - Vagotomy. 